\title{
LIBERATION NATION? QUEER REFUGEES, HOMONATIONALISM AND THE CANADIAN NECROPOLITICAL STATE
}

\author{
Nação de libertação? Refugiados queer, homonacionalismo \\ e o Estado necropolítico canadense
}

David Murray*

\begin{abstract}
This paper presents an overview of the Canadian state's refugee determination processes for persons lodging asylum claims in Canada on the basis of sexual orientation or gender identity expression (SOGIE). Canada has an international reputation for being a welcoming nation to SOGIE (as well as other categories of) refugees, a reputation that is much promoted by the Canadian government and mainstream media. However, in my ethnographic research with SOGIE refugee claimants navigating the Canadian refugee determination process, I reveal that claimants must quickly learn how to construct an 'authentically' gay, lesbian, bisexual or transgender narrative that meets refugee adjudicators' standards of credibility, or risk being identified as a 'fake' refugee, and thus face incarceration and/or deportation. I argue that sexuality now forms a crucial component of the nation-state's gate-keeping apparatus, with uneven effects for queer migrants.
\end{abstract}

Keywords: refugees; migration; queer; sexuality; Canada.

Resumo. Este artigo apresenta uma visão geral dos processos de determinação do status de refugiado do Estado canadense para pessoas que o solicitam no Canadá com base na orientação sexual ou expressão de identidade de gênero (SOGIE, em inglês). O Canadá tem uma reputação internacional de ser uma nação acolhedora para os refugiados desta categoria (assim como para outras categorias de requerentes), uma reputação promovida pelo próprio governo canadense e pela grande mídia. No entanto, em minha pesquisa etnográfica com solicitantes de refúgio da categoria SOGIE que passam pelo processo de determinação de refúgio do Canadá, eu revelo que os requerentes precisam aprender rapidamente como construir uma narrativa 'autenticamente' gay, lésbica, bissexual ou transgênero que atenda aos padrões de credibilidade ou correm o risco de serem identificados pelo juíz como 'falsos' refugiados enfrentando, assim, encarceramento e/ou deportação. Argumento que

\footnotetext{
York University, Department of Anthropology. Toronto, Canadá. E-mail: damurray@yorku.ca.
} Orcid: 0000-0002-2778-1877. 
a sexualidade agora constitui um componente crucial do aparato de controle do Estado-nação, com efeitos desiguais para os migrantes queer.

Palavras-chave: refugiados; migração; queer; sexualidade; Canadá.

Canada is a country with an international reputation for being supportive of asylum seekers. Since 1989, around 700,000 refugee claimants have come to Canada and sought protection, and half have qualified for refugee status following their hearing. The Canadian Immigration and Refugee Board (IRB) is the governmental department tasked with processing refugee applications. During the last decade, the IRB finalized between approximately 14,000 to 35,000 refugee claims annually (it is worth noting that, during the same period, Canada received fewer refugee claimants per capita compared to host countries such as Sweden, Germany, and the United States). Since the early 1990s, Canada has been accepting refugee applications on the basis of sexual orientation or gender identity expression (SOGIE), acknowledging that these are social groups who may face persecution in their home countries. A small, but consistent percentage of annual asylum decisions in Canada - 2,400 (or 13 per cent) - are based on sexual orientation or gender identity expression (Tomkinson, 2018).

Throughout the first decade of the 2000s, there was a significant amount of Canadian media coverage of lesbian gay bisexual and transgender (LGBT) refugee claimants. In much of this media coverage, Canada was regularly identified as the apex of 'progress', a 'leader' in LGBT rights and a 'haven' for LGBT individuals from around the world seeking protection from violence, persecution and discrimination. As I read these articles and watched documentaries on this topic, I noticed a common narrative arc: SOGIE refugees' countries of origin were regularly depicted as deeply homophobic, so refugees had no choice but to flee and seek refuge in Canada, where they were now thankful to find freedom and protection. I call this the 'queer migration to liberation nation' narrative, operating as a hegemonic discourse across numerous media platforms in which sexual and national identities and cultures are organized into a morality tale in which a particular formation of sexual citizenship now operates as a cornerstone of what it is to be Canadian.

However, after spending 18 months working with some of these refugee claimants in Toronto and volunteering with 2 LGBT refugee support groups, I realized there were numerous omissions, silences and gaps in the queer migration to liberation nation narrative which raised a number of questions for me: How do SOGIE refugee claimants learn to tell their story of migration and navigate the refugee determination apparatus in Canada? Why do their stories in the media sound quite different from the stories they would tell me or each other in informal contexts? Also omitted from the popular 
media queer migration to liberation nation narrative are the voices of other participants in the refugee determination process: What are the experiences of a SOGIE refugee support group volunteer, a lawyer representing a SOGIE refugee claimant, or a staff member of Canada's Immigration and Refugee Board in the assessment of a SOGIE refugee claim? What are their views of the refugee determination process? On a broader scale, how are sexual orientation and gender identity as components of the refugee determination process related to issues of immigration, nationalism and citizenship, or, put in slightly different terms, the making and unmaking of borders?

In order to answer these questions I decided to focus on how the SOGIE refugee claimant, and, to a lesser extent, some other participants in the refugee determination process, comes to understand the operations of the refugee apparatus, how they obtain the knowledge to navigate this complex apparatus, and in so doing learn to become a credible SOGIE refugee. I did this through ethnographic explorations of differentially positioned participants, locations and objects in the Canadian refugee determination process. I explored the SOGIE refugee claimant's entry into, movements through and exit from the refugee determination process, focusing on both the refugee claimant's perspective and that of other participants who interact with the claimant (such as their lawyer, support group worker, IRB Member and expert witness), in order to provide different lenses through which we may better understand how SOGIE refugee identities and narratives are produced and evaluated throughout the refugee apparatus and related to broader narratives of national belonging and citizenship (Murray, 2016).

I focused primarily on SOGIE refugee applicants who lodged their claims when they arrived at Pearson International Airport in Toronto, or who were admitted into Canada on student or visitor visas, and then lodged their claim at a Canada Immigration and Citizenship office in Toronto. These refugee applicants would first have to fill out a series of documents, including what used to be called a Personal Information Form (PIF) ${ }^{1}$, in which they would provide a narrative outlining why they were applying for refugee status and what had happened to them. The PIF, and accompanying documents, would be submitted to the IRB, and if everything was in order, a hearing date would be set, in which an IRB adjudicator would meet the applicant (who could be accompanied by a lawyer) and ask them questions about their application documents and story. The adjudicator would then decide if the applicant was 'credible' or not: If the decision was positive, the applicants would be granted a 'convention refugee' status, which allowed them to live permanently in Canada, and be put on the

\footnotetext{
In 2012, the Federal Government passed Bill C-11 which contained major changes to the structure and processes of the Immigration and Refugee Protection Act. The PIF was replaced by another document titled, "Basis of Claim" form.
} 
path towards obtaining Canadian citizenship. If the decision was negative, the applicant could be deported within a relatively short period of time (in some cases an appeal to a negative decision could be launched).

In exploring the SOGIE refugee applicant's journey through the Canadian refugee determination apparatus, I saw that the SOGIE refugee claimant must learn relatively quickly how to identify as a particular kind of 'lesbian, gay bisexual or transgender' person, in order to try and ensure that an IRB adjudicator would judge them as 'credible', that is, that they were who they said they were (ie. that they really are gay, lesbian, bisexual or transgender) and that their fear of persecution was well founded. The applicants were reminded repeatedly by their lawyers, peer support group leaders and each other that there were a number of components, characteristics and assumptions utilized by IRB Members to determine the credibility of a SOGIE refugee claim, and that if they learned and understood these assumptions and characteristics associated with "LGBT" identities, and integrated them into an appropriate narrative of identity formation and persecution based on that identity, then they stood a better chance of a successful hearing.

The personal narrative component of the Personal Information Form generated a lot of discussion and anxiety amongst refugee claimants, as they came to learn that it was a key site in which their 'credibility' would be assessed by an IRB adjudicator. Even though claimants were told by the IRB that the PIF 'is where you tell your story', they were also told by support group staff members to get a lawyer 'to help them tell their story'. Claimants thus learned that the personal narrative section of the PIF was not simply a matter of telling their 'life story' as they saw it; rather, there was a particular structure or framework for this narrative, and it must include important features or components that addressed the jurisprudential objective of determining credibility of a refugee claim. In other words, the personal narrative becomes an 'evidentiary' document: evidence is given by the claimant about his or her claim through this narrative, and that evidence is evaluated in relation to other documents and the testimony of the claimant at the hearing. So even though one lawyer told a refugee support group that the PIF must be 'in your own voice', she went on to provide some specific examples of what that voice should comment on or include, i.e. a friend's name, the distance between the house you were punched in and your friend's house that you ran to, the time of the day at which the violent event took place. These are elements of a very particular kind of storytelling, one that fits the parameters of a courtroom in which facts are elicited and tested in order to determine the truth or falseness of a defendant's claim. In other words, the personal narrative is located within and structured by the formulism and formalism of western juridical concepts and processes (Johnson, 2011, p. 62). 
Not surprisingly, listening to presentations like that of the lawyer could stir up anxiety amongst refugee claimants. Ruth, who is in her 50s, from St. Lucia, and who self identifies as lesbian, told me that the whole PIF writing process was nerve-wracking, because after she wrote and submitted it to the IRB, she remembered additional things that had happened to her that she thought were significant. She said, "there are things you try to forget, or your mind blocked because it didn't want to remember them, but they come back suddenly, maybe when you're being asked the (same) question again". For example, after she submitted her PIF to the IRB she remembered an incident where she'd been driving her car back in St. Lucia, and as she passed a man on the road he yelled 'sodomite' and threw a rock at her. She remembered hearing the window glass break, and felt a bit of the glass hit her, but thought she was ok and drove on, until at a stop sign a woman in another car looked over and told her there was blood coming down the side of her face. She ended up needing two stitches for this. But since this incident wasn't included in her PIF, her lawyer told her she wasn't supposed to talk about it at her upcoming hearing, because the adjudicator might find it 'suspicious' that Ruth was 'introducing' new information that was not on her PIF, and start to think that Ruth was not telling the truth. If the adjudicator started to doubt Ruth's story, then he might start to question whether or not Ruth was lying about her sexuality, and was just another 'illegal immigrant'. "It's this kind of business that can lead to confusion", she added.

Based on these comments, I argue that proving one's sexual orientation or gender identity in the Canadian refugee determination process is a messy business involving socio-sexual terms that carry particular socio-cultural meanings and histories (which are, themselves, in constant flux); yet, particular interpretations of these terms circulate in privileged positions within refugee discourses, policies and events. Thus, for example, an Afro-Caribbean woman from a rural, impoverished community in St. Lucia who has had sexual relations with women and men, may not identify or feel comfortable with socio-sexual identity terms like 'lesbian' or 'bisexual' used by her lawyers, support group workers and IRB Members, as these terms are freighted with particular Euro-American racial, gendered and class qualities and/or circulate with different meanings in St. Lucia. However, if she does not produce adequate documentation to support her personal narrative, answer questions, or perform in ways that reproduce the Board Member's understanding of particular sexual orientation identities like 'lesbian' or 'bisexual', then she risks failing to be "credibly" bisexual or lesbian. Thus, in addition to Cantú's observation that the asylum process requires queer applicants to attribute their persecution to a reified version of their country of origin's national culture that is cast in racialized, colonialist terms (2009, p. 55-73), I am arguing 
that the credibility of SOGIE refugee claimants is also evaluated through processes and questions that impose a prism of assumed understandings of 'real' or authentic gay, lesbian, bisexual or transgender identities that reflect primarily white, middle-class experiences and beliefs about those sexual and gendered identities; these experiences assume a universal sameness of LGBT identities, and produce pre-determined assumptions about what a handshake should feel like, how one should act in SOGIE support group settings or how a narrative of SOGIE persecution should be constructed (or conversely, when such a narrative becomes suspiciously repetitious).

These observations contribute to my overall argument that the SOGIE refugee is a new 'wrinkle' in the fabric of Canadian immigration and citizenship policies and broader narratives of Canadian identity. I argue that the impact of this newish migrant identity category and narrative ('newish' in terms of recognition by the state) is contributing to a reconfiguration of hegemonic national Canadian identity myths, such that credible SOGIE refugees, that is, an authentic or credibly gay, lesbian, bisexual or transgender refugee, are now being folded into hegemonic narratives of Canadian national identity and good citizenship. Put slightly differently, I am arguing that the refugee apparatus is contributing to the production of a new permutation of homonationalism, a highly delimited and normative narrative of same-sex sexual citizenship and national belonging, which now includes some migrant bodies, but excludes many others who do not fit the narrative's acceptable performances, characteristics, and/or aesthetics. My book's focus on how one category of queer migrants confirms and reconfigures the Canadian nation-state's hegemonic narrative of belonging employs Lisa Duggan's concept of homonormativity as "a politics that does not contest dominant heteronormative assumptions and institutions, but upholds and sustains them, while promising the possibility of a demobilized gay constituency and a privatized, depoliticized gay culture anchored in domesticity and consumption" (2003, p. 50), and extends this through Jasbir Puar's concept of 'homonationalism', which invokes a privileged relationship between post 9/11 American nationalism and a particular raced, classed and gendered formation of gay identity in opposition to the threat of racialized foreign 'others' (2007). Puar outlines how homonationalism is used to justify heightened security and militarization of US borders in order to protect "tolerant" America from the homophobic, intolerant, monstrous, racialized immigrant other.

Throughout much of the 20th century, the homosexual was the deviant, criminal or 'bad' citizen in North American discourses of nationalism and citizenship (Canaday, 2009; Kinsman, Gentile, 2010), however, over the past 40-45 years this image has been gradually replaced, through pervasive activism and legislative change, by the figure of the out, proud and productive LGBT 
citizen who claims equality with their fellow heterosexual citizens and equal rights in all domains of social, economic and political life. I argue that more recently (over the past 20-25 years), we are witnessing another permutation in discourses of acceptable sexual citizenship, with the emergence of the authentic grateful lesbian, gay, bisexual or transgender refugee. Victim of a foreign nation-state with repressive, homo- or transphobic laws, practices and attitudes, the authentic grateful LGBT refugee is rescued and given the 'gift' of a socially legitimate and politically endorsed life (citizenship) based on their 'persecuted' sexual orientation or gender identity status by an 'enlightened' democratic nation-state like Canada or the USA, where such identities and orientations are ostensibly accepted and protected. State institutions like immigration and citizenship departments (including their personnel, archives, and affiliated professions and organizations) contribute to this newish version of homonationalism, that is, the production of a 'normative' gay, lesbian, bisexual or transgender refugee, but in so doing they induce profound effects for those who do not fit the norm, i.e. for those whose sexual orientation or gender identity is evaluated to be not credible and is thus often labelled 'bogus' or 'fake'.

Thus we see how the refugee apparatus contributes towards what Puar describes as a queer necropolitics, in which the expansion of liberal politics into diverse forms of governance, surveillance and military intervention fold certain queer subjects into life while simultaneously naming and rejecting other, often racialized queer bodies (2007, p. 35-36; see Haritowarn, Kuntsman, Posocco, 2014 for an expanded discussion of queer necropolitics). We also see how the refugee apparatus is malleable and adaptable as it transforms to include sexual orientation and gender identity as possible pathways to become an acceptable citizen. However, for those who do not perform or conform to the apparatus' definitions and perceptions of what an authentic, credible SOGIE refugee and their story should look and sound like (and the evaluative processes based on those definitions and perceptions) or those who cannot produce adequate documentation demonstrating their identity and/or persecution based on their membership in this particular social group, the risk of rejection, deportation and/or incarceration-in other words, the necropolitical act, or the loss of socially legitimized life through citizenship-increases dramatically.

The majority of my ethnographic fieldwork was completed by the end of 2012, just as some major changes to the refugee determination process, brought about by the Stephen Harper Conservative government, were put into operation. These changes were designed to render the refugee determination system more 'efficient'. However, evidence from the 'front lines', that is, reports from lawyers, SOGIE support workers, refugee advocate organizations and refugee applicants themselves, indicated that the effect of the changes 
was to reconfigure and tighten the refugee apparatus even further, shrinking eligibility timelines and growing the number of categories of inadmissibility. Rohan Sajnani reported that,

The new legislation entails a swath of measures that aim to "crack down" on those immigrants who the government has not selected as economically advantageous or desirable. The measures, including shortened timelines, the increased use of detention, draconian measures for "irregular" arrivals and boat arrivals... and measures which off-load governmental responsibilities for protection onto civil society, seriously erode the protection imperative in domestic and international law. (Sajnani, 2014, p. 21)

One section of the new legislation which had a significant negative impact on SOGIE claimants was the shortening of time limits in the refugee determination process. During the period in which I conducted fieldwork, after a claimant filed a claim at a port of entry (like an airport) they would have 28 days to find a lawyer, prepare their case and submit their claim to determine eligibility. Refugee claimants, lawyers and support workers reported how difficult it was to complete all these tasks within this 28 day period. However, under the new legislation, claimants have only 15 days to do these same tasks. Another change in timing has occurred around the wait period between submitting the claim and the hearing. During my fieldwork, refugee claimants could wait from six months up to 2 years for their hearing. The delays were often due to IRB inefficiencies and backlogs caused in large part by the government's decision not to appoint a full roster of adjudicators. While this long wait period could be very stressful, it did allow SOGIE refugee claimants the time to obtain and submit to the IRB important documents from their home countries, such as letters from friends, lovers and family members, police or hospital reports, or newspaper reports that could be used a proof or evidence to validate their claim (although I argue elsewhere that documentation could equally be used to undermine a claim). This extended wait period would also allow some claimants time to join and participate in local Toronto LGBT organizations, and find some form of work (the Canadian government provides temporary work visas to refugee applicants). However, the new process places SOGIE refugee claimants in an even more precarious position, in which they have substantially less time to prepare their case file and themselves for the complexities and deeply embedded 'logics' of the refugee determination hearing.

In May 2017, the chairperson of the Immigration and Refugee Board issued a new guideline entitled, "Proceedings before the IRB Involving Sexual Orientation and Gender Identity and Expression", to address what was now recognized by the IRB as a number of problematic decisions regarding SOGIE refugee claims. Its purpose is "to promote greater understanding of cases involving SOGIE applicants and the harm individuals may face due to their nonconformity with socially accepted SOGIE norms". Under section 3.1, the 
guidelines acknowledge that, "Depending on factors such as race, ethnicity, religion, faith or belief system, age, disability, health status, social class and education, individuals with diverse sexual orientation and gender identity expressions recognize and act on these expressions differently" (p. 69) This nuanced, intersectional 'guideline' also recognizes that the harms experienced by diverse SOGIE refugees may be compounded and unique as the result of the confluence of racial or ethnic identity with sexual orientation or gender identity expression. It is still too early to determine the effectiveness of the guidelines, but recent research by Rinaldi and Fernando (2019) indicates that there have not been any substantial changes in IRB decision making processes, which continue to apply stereotypes when processing (and rejecting) diverse SOGIE applications. This is not all that surprising, given that the state refugee apparatus is still predicated on separating 'real' from 'fake' refugees through a quasi-juridical process administered by a bureaucratic regime invested in both securitizing borders despite the acceptance of a new highly delimited form of sexual citizenship premised upon specific assemblage of socio-cultural, racial, and economic characteristics.

In my book based on this research (Murray, 2016), I provide some brief updates on a few of the key participants I worked with, as I wanted to show how these people's lives continued on after the refugee claim hearing and decision, as most media coverage and refugee research focuses only on the period of the refugee application. In these updates, we witness the profound significance and effects of the refugee apparatus on the lives of these individuals, particularly the impact of a positive or negative decision on a refugee claim, but we also see ongoing dilemmas, desires and choices that existed before and after the refugee determination process, resulting in diverse feelings and actions towards the present and future. We see, at least from the ethnographer's perspective, how some individuals 'live on' and begin to prosper in Toronto, while others stagnate, fade or disappear abruptly. Some of the participants I worked with whose refugee claim had been successful were becoming increasingly frustrated because they were having trouble finding a job in Toronto or saving enough money to be able to move out of a friend's or relative's home to be able to live on their own. Others were planning their futures which included attending college, finding a romantic partner or saving for gender-transformative surgeries. However, there were also participants with whom I suddenly lost touch and couldn't find. The abrupt silence from some research participants like Odu, a bisexual man from Nigeria, whose refugee claim was rejected and identified for deportation procedures and who then changed his phone number and dropped all contact with me and his SOGIE support group facilitators, illustrates the harsh reality of the refugee apparatus, and its necropolitical powers: Odu may or may not still be in 
Canada, he may or may not have returned to Nigeria, and he may or may not be in hiding there or somewhere in Canada. But in terms of his 'citizenship' status, in the legal and bureaucratic components of the refugee apparatus, he had been deemed 'bogus', and he subsequently disappeared from the social networks he had been involved with-in other words, social death.

Through Odu's story we thus see the refugee apparatus operating in a permanent state of exception (Agamben, 2005), continually reexamining itself for 'faults' 'failures' and 'blockages' that allow what it deems as 'illegal or dangerous' bodies to pass through national borders. The refugee apparatus continually reviews and revises, with the impossible goal of creating a fool proof 'system' which can faultlessly figure out the genuine refugee. This nervous, distrustful, labile apparatus awards legally recognized life to some to some, but takes life from many others.

\section{References}

AGAMBEN, Giorgio. State of Exception. Chicago: University of Chicago Press, 2005.

CANADAY, Margot. The Straight State: Sexuality and Citizenship in 20th Century America. Princeton, NJ: Princeton University Press, 2009.

CANTÚ, Lionel Jr. The Sexuality of Migration: Border Crossings and Mexican Immigrant Men. New York: New York University Press, 2009.

DUGGAN, Lisa. The Twilight of Equality? Neoliberalism, Cultural Politics and the Attack on Democracy. Boston, MA: Beacon Press, 2003.

HARITAWORN, Jin; KUNTSMAN, Adi; POSOCCO, Silvia (eds.). Queer Necropolitics. London: Routledge, 2014.

JOHNSON, Toni A. M. On Silence, Sexuality and Skeletons: Reconceptualizing Narrative in Asylum Hearings. Social and Legal Studies, v. 20, n. 1, p. 57-78, 2011. KINSMAN, Gary; GENTILE, Patricia. The Canadian War on Queers: National Security as Sexual Regulation. Vancouver: University of British Columbia Press, 2010.

MURRAY, David A. B. Real Queer: Sexual Orientation and Gender Identity Refugees in the Canadian Refugee Apparatus. London: Rowman and Littlefield, 2016.

PUAR, Jasbir. Terrorist Assemblages: Homonationalism in Queer Times. Durham: Duke University Press, 2007.

RINALDI, Jen; SHANTI, Fernando. Queer Credibility in the Homonation-State: Interrogating the Affective Impacts of Credibility Assessments on Racialized Sexual Minority Refugee Claimants. Refuge: Canada's Journal on Refugees, v. 35, n. 1, p. 32-42, 2019.

SAJNANI, Rohan. The Impact of Canada's new Immigration Regime. Toronto: Envisioning Global LGBT Human Rights, 2014.

TOMKINSON, Sule. Who are you afraid of and why? Inside the black box of refugee tribunals. Canadian Public Administration, v. 61, n. 2, p. 184-204, 2018. 